\title{
The tobacco industry in the time of COVID-19: time to shut it down?
}

\author{
Marita Hefler (i) , ${ }^{1}$ Coral E Gartner (i) 2,3
}

The COVID-19 pandemic which originated in China in late 2019 has spread rapidly and taken much of the world by surprise, creating a health and economic emergency likely to have significant impacts for many years. The magnitude of the threat has forced both governments and businesses to urgently elevate public health above economic principles, adapt and reinvent in an attempt to contain the spread of the disease. Business closures have created sudden and widespread unemployment. $^{1}{ }^{2}$ Nationalisation of industries such as private healthcare ${ }^{3}$ and airlines ${ }^{4}$ has happened, or is being considered. Governments are pumping money into their economies through stimulus packages and income support, where previously austerity was the order of the day. ${ }^{5}$ In the private sector, car makers are pivoting to making medical equipment, ${ }^{7}$ alcohol companies are manufacturing hand sanitiser ${ }^{8}$ and digital transformation across many sectors is being fast-tracked, ${ }^{9}$ among other examples of business adaptation. $^{10}$

The COVID-19 pandemic is an extraordinary event requiring extreme measures due to the potential for healthcare systems to be overwhelmed. However, the tobacco epidemic exerts a greater, sustained strain. At the time of writing, the global death toll from COVID-19 stood at just over 53 $000,{ }^{11}$ compared with over 8 million from tobacco use annually (including deaths attributed to secondhand smoke exposure). ${ }^{12}$ The cumulative death toll from tobacco use was 100 million during the 20th century and estimates indicate this could reach 1 billion this century. ${ }^{13}$ The number of COVID-19 deaths will likely continue to rise for many months, with the final toll dependent on how aggressively individual countries implement mitigation

\footnotetext{
${ }^{1}$ Wellbeing and Preventable Chronic Diseases Division, Menzies School of Health Research, Charles Darwin University, Casuarina, Northern Territory, Australia ${ }^{2}$ Faculty of Medicine, School of Public Health, University of Queensland, Herston, Queensland, Australia ${ }^{3}$ Queensland Alliance for Environmental Health Sciences, University of Queensland Faculty of Health and Behavioural Sciences, Woolloongabba, Queensland, Australia
}

Correspondence to Dr Marita Hefler, Wellbeing and Preventable Chronic Disease, Menzies School of Health Research, Charles Darwin University, Casuarina, NT 0811, Australia; marita.hefler@menzies.edu.au measures. In China, there have been just over 3300 COVID-19 deaths ${ }^{11}$ compared with approximately 1 million each year from tobacco. ${ }^{14}$ In Italy, which currently has the highest deaths per million of the population, there have been nearly 14000 deaths from COVID-19, ${ }^{11}$ compared with 93300 each year from tobacco. ${ }^{15}$ Both countries appear to be near the peak of COVID-19 infections, although there is the danger of a second wave. Nonetheless, the COVID-19 pandemic is likely to be short term, as a vaccine and effective treatments become available. COVID-19 is unlikely to ever match the relentless and growing annual toll from tobacco smoking.

Although limited, emerging evidence (unsurprisingly) suggests that smokers who are hospitalised for COVID-19 are at risk of more severe outcomes than non-smokers. ${ }^{16}$ Despite this, the tobacco industry appears unperturbed. According to British American Tobacco (BAT), consumers continue to purchase tobacco products, even in the hardest hit areas. BAT Chief Executive Officer Jack Bowles stated: 'We don't see any change in patterns of consumption of cigarettes because of Covid-19...It is a daily purchase, so consumers continue to go to shop, even in Italy and France where tobacco shops are still open. ${ }^{17}$ (In some European countries, tobacconists were treated as essential retailers and excluded from general shutdowns.) His sentiment is backed by some investment analysts, who recommend tobacco stocks as a good buy during the COVID-19 market turmoil. ${ }^{18} 19$

The industry has not been completely immune to negative impacts of the virus: in March, Philip Morris USA suspended production at its Richmond manufacturing centre after two employees tested positive for COVID-19. Altria's Vice Chairman and Chief Financial Officer Billy Gifford stated that the company is 'committed to protecting the safety and well-being of our employees, contractors, their families and the communities where we operate', and that the company has 'been actively implementing plans to minimize business disruptions and their potential impact to our employees, consumers and customers'. ${ }^{20}$ The contradiction between shutting down to protect the community from a deadly virus, while minimising disruption to continue to produce the most lethal consumer product in history, is farcical. However, it raises a serious question: why should the tobacco industry continue during a pandemic which is fundamentally changing the world?

The case for phasing out cigarette sales has been clearly and persuasively argued. ${ }^{21}$ It takes on added urgency during this pandemic. The increased risk of severe outcomes for smokers hospitalised with COVID $-19,{ }^{16}$ and the reductions in hospitalisations generally that result from quitting smoking, ${ }^{22} 23$ may provide the impetus for restricting cigarette sales while health services are strained to the breaking point, as has been called for by the New York State Academy of Family Physicians. ${ }^{24}$ In one Australian state, alcohol sales have already been limited because the health service cannot spare the resources to address alcohol-related issues during this pandemic. $^{25}$ COVID-19 shutdowns have enforced numerous constraints on people that restrict liberty and fulfilment of basic human needs. Strict physical distancing deprives people of physical, and in some cases meaningful social, contact. Exclusion from school impinges on one of the most basic rights of children, to receive an education. Panic buying has forced shops to limit purchases of staple foods. Many businesses that make positive contributions to society will not survive the economic consequences of these important public health measures. In contrast, tobacco retailing, which negatively impacts the health, social and economic well-being of communities, has no social licence.

For smokers, the changed social circumstances could provide an opportunity to quit smoking. Research shows that easy retail availability of tobacco products increases relapse among those trying to quit. ${ }^{26}$ Reduced or no availability of cigarettes would enhance these quit efforts. Given the role of social cues in relapse during quit attempts, ${ }^{27}$ self-isolation may make quitting easier for some, although there is a need to provide support for people to manage stress and mitigate mental health risks. Both mental health support and smoking cessation assistance should be treated as essential services and prioritised at this time of heightened stress, particularly for the most vulnerable who are at highest risk. Some quit support services are using this opportunity to promote quitting and support people to do so. ${ }^{28}$ In this context, now is an opportune time to move towards removing cigarettes from general retail sale. While there are major limitations on transport 
and movement of people, tobacco supply chains could be redeployed for more essential purposes. The increased control and scrutiny of movement of goods and people at this time would also likely make controlling illicit markets easier.

The tobacco cigarette pandemic is like COVID-19 in slow motion. The need to 'flatten the curve' is urgent. The fact that the tobacco epidemic curve is only partially flattened (in some countries) is widely accepted because the cigarette pandemic has been with us for so long, and the tobacco industry has been extraordinarily successful at conditioning the public and policymakers to accept it as a given. If governments had acted to protect the public from tobacco with a fraction of the effort (and financial investment) they have exerted to control this coronavirus, many millions of lives could have been saved, and underlying demand on health services significantly reduced. ${ }^{29}$ The world will emerge from the COVID-19 pandemic changed. Phasing out cigarette sales would be an enormous long-term gain for public health. However, it is essential to act quickly, because-like containing COVID-19_delaying decisive action will cost many lives.

Twitter Marita Hefler @m_hef and Coral E Gartner @ CoralGartner

Funding The authors have not declared a specific grant for this research from any funding agency in the public, commercial or not-for-profit sectors.

Competing interests None declared.

Patient consent for publication Not required.

Provenance and peer review Not commissioned; internally peer reviewed.

This article is made freely available for use in accordance with BMJ's website terms and conditions for the duration of the covid- 19 pandemic or until otherwise determined by BMJ. You may use, download and print the article for any lawful, non-commercial purpose (including text and data mining) provided that all copyright notices and trade marks are retained.

(C) Author(s) (or their employer(s)) 2020. No commercial re-use. See rights and permissions. Published by BMJ.

\section{A) Check for updates}

To cite Hefler M, Gartner CE. Tob Control 2020;29:245-246.

Published Online First 6 April 2020

Tob Control 2020;29:245-246.

doi:10.1136/tobaccocontrol-2020-055807

\section{ORCID iDs}

Marita Hefler http://orcid.org/0000-0002-1709-1098 Coral E Gartner http://orcid.org/0000-0002-6651-8035

\section{REFERENCES}

1 Holpuch A. 'What am I supposed to do?': Covid-19 sparks mass unemployment across US Surry Hills. Australian Edition, 2020. Available: https://www. theguardian.com/business/2020/mar/25/usunemployment-coronavirus-hospitality-food-industriesclaims [Accessed 26 Mar 2020].

2 Worthington B. People urged to go home as lines form around Centrelink offices due to coronavirus, Stuart Robert admits not Anticipating MyGov demand: Australian Broadcasting Corporation, 2020. Available: https://www.abc.net.au/news/2020-03-24/centrelinkminister-stuart-robert-not-anticipate-coronavirus/ 12080612 [Accessed 26 Mar 2020].

3 Payne A. Spain has nationalized all of its private hospitals as the country goes into coronavirus lockdown Surry hills: pedestrian, 2020. Available: https://www. businessinsider.com.au/coronavirusspain-nationalises-private-hospitals-emergency-covid19-lockdown-2020-3 [Accessed 26 Mar 2020].

4 Pallini T. Italy just took full ownership of its national airline Alitalia to save it from collapse amid the coronavirus crisis. here's the carrier's full troubled history. Surry hills: pedestrian, 2020. Available: https:// www.businessinsider.com. au/alitalia-nationalized-byitaly-history-2020-3 [Accessed 26 Mar 2020].

5 Bremer B, Matthus M. The Coronavirus is Reducing Merkel's EU Legacy to Ashes Washingon: THE SLATE GROUP, 2020. Available: https://foreignpolicy.com/ 2020/03/17/coronavirus-germany-merkel-eu-legacy/ [Accessed 26 Mar 2020].

6 Verrender I. Scott Morrison's coronavirus stimulus package shows he has finally learnt to love deficits Canberra: Australian Broadcasting Corporation; 2020 [updated 23/3/2020. Available from:. Available: https://www.abc.net.au/news/2020-03-23/ coronavirus-morrison-learnt-to-love-deficits/12079792

7 Harper J. Coronavirus: Carmakers answer pleas to make medical supplies London: British Broadcasting Corporation, 2020. Available: https://www.bbc.com/ news/business-51956880 [Accessed 26 Mar 2020].

8 Griner D. Diageo and Anheuser-Busch join alcohol brands pivoting to free sanitizer New York, 2020. Available: https://www.adweek.com/creativity/diageoand-anheuser-busch-join-alcohol-brands-pivoting-tofree-sanitizer/ [Accessed 26 Mar 2020].

9 Marr B. How the COVID-19 pandemic is Fast-Tracking digital transformation in companies new Jersey, 2020. Available: https://www.forbes.com/sites/bernardmarr/ 2020/03/17/how-the-covid-19-pandemic-is-fasttracking-digital-transformation-in-companies/\# 4eabda5ca8ee [Accessed 26 Mar 2020].

10 Handley L. Distilleries making hand sanitizer? how small businesses are pivoting due to the coronavirus new Jersey, 2020. Available: https://www.cnbc.com/ 2020/03/20/coronavirus-how-small-businesses-arepivoting-due-to-the-virus.html [Accessed $26 \mathrm{Mar}$ 2020].

11 Center for Systems Science and Engineering (CSSE) at Johns Hopkins University (JHU). Coronavirus COVID-19 global cases Baltimore: JHU, 2020. Available: https:// coronavirus.jhu.edu/map.html [Accessed $26 \mathrm{Mar}$ 2020].

12 Stanaway JD, Afshin A, Gakidou E, et al. Global, regional, and national comparative risk assessment of 84 behavioural, environmental and occupational, and metabolic risks or clusters of risks for 195 countries and territories, 1990-2017: a systematic analysis for the global burden of disease study 2017. The Lancet 2018;392:1923-94.

13 Jha P. Avoidable deaths from smoking: a global perspective. Public Health Reviews 2011;33:569-600.
14 Chen Z, Peto R, Zhou M, et al. Contrasting male and female trends in tobacco-attributed mortality in China: evidence from successive nationwide prospective cohort studies. Lancet 2015;386:1447-56.

15 Drope J, Schluger N, Cahn Z, et al. The tobacco atlas. Atlanta: American Cancer Society and Vital Strategies, 2018.

16 Vardavas Cl, Nikitara K. COVID-19 and smoking: a systematic review of the evidence. Tobacco Induced Diseases 2020;18.

17 Tobacco Reporter. Bat unaffected by virus outbreak Raleigh, 2020. Available: https://tobaccoreporter.com/ 2020/03/19/bat-unaffected-by-outbreak/ [Accessed 26 Mar 2020].

18 Williams S. Coronavirus income stocks: 7 highyield Dividend stocks to buy right now 2020, 2020. Available: https://www.nasdaq.com/articles/ coronavirus-income-stocks\%3A-7-high-yield-dividendstocks-to-buy-right-now-2020-03-23 [Accessed 26 Mar 2020].

19 Sun L. These 3 Dividend stocks are immune to the coronavirus crisis, 2020. Available: https://www.fool. com/investing/2020/02/19/these-3-dividend-stocksare-immune-to-the-coronavi.aspx [Accessed $26 \mathrm{Mar}$ 2020].

20 Freeman V. Philip Morris USA suspending operations after 2nd employee tests positive for COVID-19 Richmond: Scripps media, Inc, 2020. Available: https:// www.wtvr.com/news/coronavirus/philip-morris-usasuspending-operations-after-2nd-employee-testspositive-for-covid-19 [Accessed 26 Mar 2020].

21 Smith EA, Malone RE. An argument for phasing out sales of cigarettes. Tob Control 2019:tobaccocontrol-2019-055079.

22 Hurley SF. Short-Term impact of smoking cessation on myocardial infarction and stroke hospitalisations and costs in Australia. Med J Aust 2005;183:13-17.

23 Godtfredsen NS, Vestbo J, Osler M, et al. Risk of hospital admission for COPD following smoking cessation and reduction: a Danish population study. Thorax 2002;57:967-72.

24 Einsidler N. NYSAFP calls for ban on the sale of all tobacco and vaping products during pandemic New York, 2020. Available: https://wbng.com/2020/03/22/ nysafp-calls-for-ban-on-the-sale-of-all-tobacco-andvaping-products-during-pandemic/ [Accessed $26 \mathrm{Mar}$ 2020].

25 Kagi J. Coronavirus outbreak prompts new restrictions on alcohol sales in WA bottle shops: Australian Broadcasting Corporation, 2020. Available: https:// www.abc.net.au/news/2020-03-25/coronaviruscovid-19-wa-alcohol-sales-from-bottle-shops-limited/ 12087974 [Accessed 26 Mar 2020].

26 Chaiton MO, Mecredy G, Cohen J. Tobacco retail availability and risk of relapse among smokers who make a quit attempt: a population-based cohort study. Tobacco Control 2018;27:163.

27 Hitchman SC, Fong GT, Zanna MP, et al. The relation between number of smoking friends, and quit intentions, attempts, and success: findings from the International tobacco control (ITC) four country survey. Psychol Addict Behav 2014;28:1144-52.

28 Public Health Slough Borough Council. Quit for Covid slough, 2020. Available: https://www. publichealthslough.co.uk/campaigns/health-at-home/ [Accessed 26 Mar 2020].

29 Bhopal S, Bola G, Hughes R, et al. Can we improve the NHS's ability to tackle covid-19 through emergency public health interventions? 2020. Available: https:// blogs.bmj.com/bmj/2020/03/24/can-we-improve-thenhss-ability-to-tackle-covid-19-through-emergencypublic-health-interventions/ [Accessed 26 Mar 2020]. 